\title{
Bond Characteristics of ASTM A1035 Steel Reinforcing Bars
}

\author{
by Hatem M. Seliem, Amr Hosny, Sami Rizkalla, Paul Zia, Michael Briggs, Shelby Miller, David \\ Darwin, JoAnn Browning, Gregory M. Glass, Kathryn Hoyt, Kristen Donnelly, and James O. Jirsa
}

\begin{abstract}
The results of a coordinated research program on the bond characteristics of the high-strength steel reinforcing bars that conform to ASTM A1035 are presented. Concrete with nominal strengths of 5000 and 8000 psi (35 and $55 \mathrm{MPa}$ ) were used. Sixtynine large-scale beam-splice specimens were tested. Maximum bar stresses are compared with predictions obtained using the bond equations in the ACI 318-05 code provisions and those proposed by ACI Committee 408. Maximum stress levels of 120, 110, and $96 \mathrm{ksi}$ (830, 760, and $660 \mathrm{MPa}$ ) were developed in No. 5, No. 8, and No. 11 (No. 16, No. 25, and No. 36) bars, respectively, not confined by transverse reinforcement. Providing confinement for No. 8 and No. 11 (No. 25 and No. 36) spliced bars using transverse reinforcement allowed stresses of up to $150 \mathrm{ksi}$ (1035 MPa) to be developed. The ACI Committee 408 equation provides a reasonable estimate of the strength for both unconfined and confined splices using a strength reduction factor ( $\phi$-factor) of 0.82 and design parameters (cover, spacing, and concrete strengths) comparable to those used in this test program. The design equations in ACI 318 are less conservative, with a large percentage of the developed/calculated strength ratios below 1.0, and should not be used for development and splice design with high-strength reinforcing steel in their present form.
\end{abstract}

Keywords: bond; concrete cover; confinement; development length; highstrength steel; reinforcement; splice length.

\section{INTRODUCTION}

In structural concrete design, adequate bond between the reinforcing steel and concrete is essential. The current ACI code provisions ${ }^{1}$ for bond and development length of reinforcement are empirical relationships based on the reports of ACI Committee 408 and other publications in the literature. ACI Committee $408^{2}$ has developed its own empirical expression based on a larger database than that used to formulate the provisions in the ACI Code. Although ACI Committee 408 has an extensive database, virtually all the data were obtained from tests using reinforcement with specified yield strengths of $80 \mathrm{ksi}(555 \mathrm{MPa})$ or less. The objective of this research program is to determine if provisions derived from tests of bars with yield strengths less than $80 \mathrm{ksi}(555 \mathrm{MPa})$ are applicable for splices of reinforcement with much higher yield strength.

MMFX steel is a new high-strength reinforcement that meets the requirements of ASTM A1035. ${ }^{3}$ It is characterized by a high tensile strength and a stress-strain curve without a well-defined yield plateau. Yield strength is determined using the $0.2 \%$ offset method. To use this reinforcement efficiently for concrete structures, it is necessary to determine whether the current code provisions are applicable and, if not, to develop new design recommendations.

North Carolina State University (NCSU) organized a cooperative research program on the bond behavior of MMFX reinforcing steel, in partnership with the University of Kansas (KU) and the University of Texas at Austin (UT). By conducting independent tests concurrently at three institutions, it was possible to complete the research more rapidly and to cross-check test results, providing greater reliability and confidence. Each university tested 22 largescale beam-splice specimens. A summary of the test program and an analysis of the results of the coordinated research program are presented in this paper.

\section{RESEARCH SIGNIFICANCE}

The equations for development lengths and splice lengths of reinforcing steel bars in ACI $318-05^{1}$ and ACI 408R-03 are empirical. These equations are based on research conducted using steel with yield strengths of $80 \mathrm{ksi}(555 \mathrm{MPa})$ or less. It is not clear, however, if the current bond equations can be applied to ASTM A $1035^{3}$ reinforcing steel because of its high tensile strength and nonlinear stress-strain behavior. To use the high-strength characteristics of the steel, it is essential to examine the applicability of the current design procedures for splice and development length to ASTM A1035 steel bars.

\section{EXPERIMENTAL PROGRAM Mechanical properties of ASTM A1035 steel bars}

Tensile specimens of ASTM A1035 $5^{3}$ steel bars and conventional Grade 60 (Grade 420) steel bars were tested in accordance with ASTM A370 4 for comparison. The stressstrain characteristics of both steel bars are shown in Fig. 1. The figure shows that ASTM A $1035^{3}$ bars exhibit a nearly linear stress-strain relationship up to approximately $100 \mathrm{ksi}$ (690 MPa), followed by a nonlinear relationship up to a

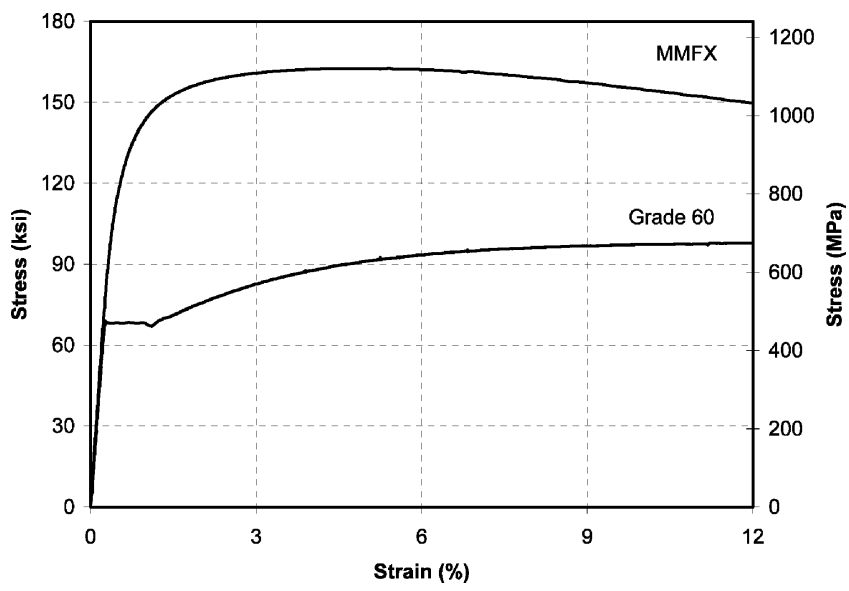

Fig. 1-Stress-strain characteristics of ASTM A1035 and Grade 60 steel bars.

ACI Structural Journal, V. 106, No. 4, July-August 2009.

MS No. S-2008-074.R2 received March 24, 2008, and reviewed under Institute publication policies. Copyright (C) 2009, American Concrete Institute. All rights reserved, including the making of copies unless permission is obtained from the copyright proprietors. Pertinent discussion including author's closure if any, will be published in the May-June 2010 ACI Structural Journal if the discussion is received by January 1, 2010. 
ACI member Hatem M. Seliem is a Postdoctoral Research Associate at the Constructed Facilities Laboratory of North Carolina State University, Raleigh, NC, from which he received his $P h D$ in 2007.

ACI member Amr Hosny is a Graduate Research Assistant at the Constructed Faciliteis Laboratory of North Carolina State University, from which he received his MSc in 2007.

Sami Rizkalla, FACI, is a Distinguished Professor of Civil and Construction Engineering, Director of the Constructed Facilities Laboratory, and Director of the NSF Industry/ University Cooperative Research Center at North Carolina State University.

ACI Honorary Member Paul Zia is a Distinguished University Professor Emeritus at North Carolina State University. He is an ACI Past President.

ACI member Michael Briggs is completing his MSc in civil engineering at the University of Kansas, Lawrence, $K S$. He received his BSc in civil engineering from Michigan State University, East Lansing, MI.

ACI member Shelby Miller is an Engineer with the Kansas Department of Transportation. She received her BSc in architectural engineering and MSc in civil engineering from the University of Kansas.

David Darwin, FACI, is the Deane E. Ackers Distinguished Professor of Civil, Environmental and Architectural Engineering and Director of the Structural Engineering and Materials Laboratory at the University of Kansas. He is an ACI Past President.

ACI member JoAnn Browning is an Associate Professor of civil, environmental, and architectural engineering at the University of Kansas.

Gregory M. Glass is an Engineer with International Bridge Technologies in San Diego, CA. He received his MSc from the University of Texas at Austin, Austin, TX, in 2007.

Kathryn Hoyt is an Engineer with Baker Engineering and Risk Consultants, San Antonio, TX. She received her MSc from the University of Texas at Austin.

Kristen Donnelly is a Graduate Research Assistant at the University of Texas at Austin.

ACI Honorary Member James O. Jirsa holds the Janet S. Cockrell Centennial Chair in Engineering at the University of Texas at Austin. He is an ACI Past President.

tensile strength of $163 \mathrm{ksi}(1125 \mathrm{MPa})$. Because the steel does not exhibit a well-defined yield point, the yield strength is determined using the $0.2 \%$ offset method as $120 \mathrm{ksi}$ (830 MPa). The initial modulus of elasticity is $29,000 \mathrm{ksi}$ $(200 \mathrm{GPa})$, dropping slowly as the stress approaches $100 \mathrm{ksi}$ (690 $\mathrm{MPa}$ ), and dropping more rapidly thereafter. The manufacturer supplied bars of each diameter used by the three research groups from the same heats of steel.

\section{Test specimens}

Large-scale beam-splice specimens were used to study the bond characteristics of ASTM A $1035^{3}$ steel reinforcing bars embedded in normal-strength concrete. Beam-splice specimens were used, as recommended by ACI Committee 408, ${ }^{2}$ because they provide a realistic state of stress, with both the reinforcing steel and the concrete subjected to tension, as is the case on the tension side of reinforced concrete members.

The study was designed to include the following parameters, which are deemed important for bond strength: splice length, bar size, concrete cover, concrete strength, and level of confinement provided by transverse reinforcement. The test specimens were designed to have equal clear side and bottom (as-cast) concrete covers, with clear bar spacing equal to twice the selected concrete cover. The complete test matrix for the three universities is given in Table 1 (notation discussed below).

The experimental program at each university included 22 beam-splice specimens. Three additional specimens were tested at UT, making a total of 69 specimens. The test matrix includes 12 duplicate specimens to provide a means of crosschecking procedures and test results. The duplicate specimens are highlighted in Table 1. Because the duplicate specimens were designed independently and cast at three different universities, there are slight differences in details such as cross section, stirrup spacing, and splice length. The beam specimens with No. 8 and No. 11 (No. 25 and No. 36) bars contained two splices, while the slab specimens with No. 5 (No. 16) bars contained four splices, as shown in Fig. 2. The splice lengths and quantities of transverse reinforcement to achieve the selected stress levels in the bars were calculated using the design equation recommended by ACI Committee $408^{2}$ (Eq. (4-11a) of ACI 408R-03), with a strength reduction factor ( $\phi$-factor) of 1.0.

A five-part notation system is used to identify the test specimens as follows: the first part, "5, 8, or 11," designates the size of the spliced bars, and the second part, "5 or 8,"

Table 1-Collective test matrix

\begin{tabular}{|c|c|c|c|c|c|c|c|}
\hline$f_{c}^{\prime}, \mathrm{ksi}$ & Bar size & \multicolumn{2}{|c|}{ University of Kansas (KU) } & \multicolumn{2}{|c|}{ North Carolina State University (NCSU) } & \multicolumn{2}{|c|}{ University of Texas at Austin (UT) } \\
\hline \multirow{9}{*}{5} & \multirow{3}{*}{5} & \multicolumn{2}{|c|}{ Cover (in.) } & \multicolumn{2}{|c|}{ Cover (in.) } & \multicolumn{2}{|c|}{ Cover (in.) } \\
\hline & & $3 / 4$ & 2.0 & $3 / 4$ & 2.0 & $3 / 4$ & 2.0 \\
\hline & & $\begin{array}{l}\mathrm{O}-\mathrm{C} 0 \\
\mathrm{X}-\mathrm{C} 0\end{array}$ & - & - & - & $\begin{array}{l}\text { O-C0 } \\
\text { X-C0 }\end{array}$ & $\begin{array}{l}\mathrm{O}-\mathrm{C} 0 \\
\mathrm{X}-\mathrm{C} 0\end{array}$ \\
\hline & \multirow{3}{*}{8} & \multicolumn{2}{|c|}{ Cover (in.) } & \multicolumn{2}{|c|}{ Cover (in.) } & \multicolumn{2}{|c|}{ Cover (in.) } \\
\hline & & 1.5 & 2.5 & 1.5 & 2.5 & 1.5 & 2.5 \\
\hline & & $\begin{array}{l}\mathrm{O}-\mathrm{C} 0, \mathrm{C} 1, \mathrm{C} 2 \\
\mathrm{X}-\mathrm{C} 0, \mathrm{C} 1, \mathrm{C} 2\end{array}$ & - & - & $\begin{array}{l}\mathrm{O}-\mathrm{C} 0, \mathrm{C} 2, \mathrm{C} 3 \\
\mathrm{X}-\mathrm{C} 0, \mathrm{C} 2, \mathrm{C} 3\end{array}$ & $\begin{array}{l}\mathrm{O}-\mathrm{C} 0, \mathrm{C} 2 \\
\mathrm{X}-\mathrm{C} 0, \mathrm{C} 2\end{array}$ & - \\
\hline & \multirow{3}{*}{11} & \multicolumn{2}{|c|}{ Cover (in.) } & \multicolumn{2}{|c|}{ Cover (in.) } & \multicolumn{2}{|c|}{ Cover (in.) } \\
\hline & & 2.0 & 3.0 & 2.0 & 3.0 & 2.0 & 3.0 \\
\hline & & - & - & $\mathrm{O}-\mathrm{C} 0, \mathrm{C} 2, \mathrm{C} 3$ & - & - & $\mathrm{O}-\mathrm{C} 0, \mathrm{C} 1, \mathrm{C} 2$ \\
\hline \multirow{6}{*}{8} & \multirow{3}{*}{8} & \multicolumn{2}{|c|}{ Cover (in.) } & \multicolumn{2}{|c|}{ Cover (in.) } & \multicolumn{2}{|c|}{ Cover (in.) } \\
\hline & & 1.5 & 2.5 & 1.5 & 2.5 & 1.5 & 2.5 \\
\hline & & - & $\begin{array}{l}\mathrm{O}-\mathrm{C} 0, \mathrm{C} 1, \mathrm{C} 2 \\
\mathrm{X}-\mathrm{C} 0, \mathrm{C} 1, \mathrm{C} 2\end{array}$ & $\begin{array}{l}\mathrm{O}-\mathrm{C} 0, \mathrm{C} 2 \\
\mathrm{X}-\mathrm{C} 0, \mathrm{C} 2\end{array}$ & - & $\begin{array}{l}\mathrm{O}-\mathrm{C} 0, \mathrm{C} 1, \mathrm{C} 2 \\
\mathrm{X}-\mathrm{C} 0, \mathrm{C} 1, \mathrm{C} 2\end{array}$ & - \\
\hline & \multirow{3}{*}{11} & \multicolumn{2}{|c|}{ Cover (in.) } & \multicolumn{2}{|c|}{ Cover (in.) } & \multicolumn{2}{|c|}{ Cover (in.) } \\
\hline & & 2.0 & 3.0 & 2.0 & 3.0 & 2.0 & 3.0 \\
\hline & & $\begin{array}{l}\text { O-C0,C1,C2 } \\
\text { X-C0,C1,C2 }\end{array}$ & - & - & $\begin{array}{l}\mathrm{O}-\mathrm{C} 0, \mathrm{C} 2, \mathrm{C} 3 \\
\mathrm{X}-\mathrm{C} 0, \mathrm{C} 2, \mathrm{C} 3\end{array}$ & - & - \\
\hline $\mathrm{T}$ & tal & & & & & & \\
\hline
\end{tabular}


designates the nominal concrete strength in ksi. The third part, "O or X," designates the selected splice length to achieve a specified stress level of 80 or $100 \mathrm{ksi}$ (555 or $690 \mathrm{MPa}$ ), respectively, without confining transverse reinforcement. The fourth part designates the confinement provided by the transverse reinforcement: $\mathrm{C} 0$ designates an unconfined splice; and $\mathrm{C} 1, \mathrm{C} 2$, or $\mathrm{C} 3$ designate the three selected confinement levels in the splice zone, providing increases in bar stress of 20,40, and $80 \mathrm{ksi}(140,275$, and $555 \mathrm{MPa})$. The fifth part designates the selected concrete cover in inches.

The details for the test specimens are given in Tables 2 to 4 . The stirrups provided outside of the test zone, shown in Fig. 2, were designed to prevent premature shear failure of the test beams. All stirrups within the splice region were fabricated from No. 4 (No. 13) Grade 60 (Grade 420) bars. Both No. 4 and No. 5 (No. 13 and No. 16) bars were used as shear reinforcement.

The specimens were cast with the spliced bars at the bottom of the form to preclude top bar effects. For testing, the specimens were turned over to place the spliced bars near the top surface to facilitate mapping and measuring the cracks and observing the behavior of the splice zone.

\section{Test setup and instrumentation}

The specimens were tested in four-point bending to develop a constant moment zone where the spliced bars were located (refer to Fig. 3). The load was applied using hydraulic jacks reacting against the laboratory strong floor. At NCSU and UT, the test beams were supported by steel

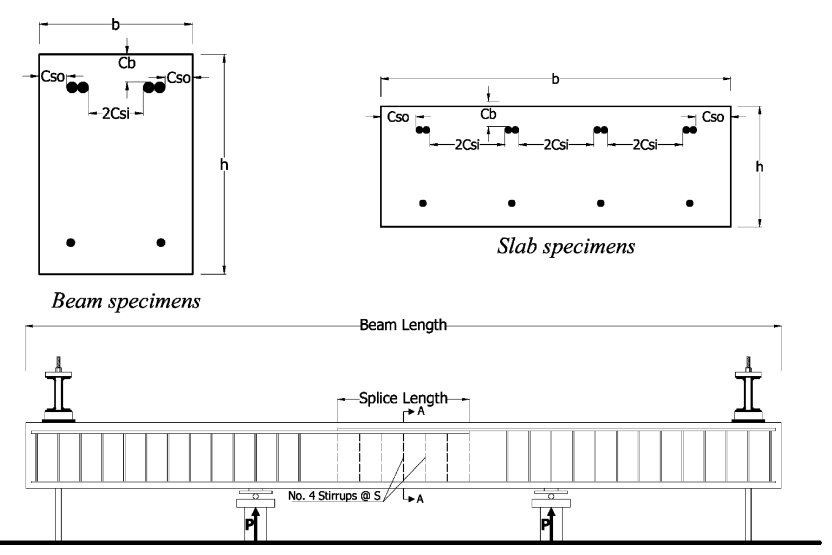

Fig. 2-Reinforcement details of test specimens. beams tied down to the strong floor using prestressing bars. Load cells were placed between the test specimen and the hydraulic jacks to measure the applied load. At $\mathrm{KU}$, the beam was supported at the ends of the constant moment region and load was applied by pulling down through the strong floor at the ends of the beam. Four electrical resistance strain gauges were attached to the spliced bars before casting the concrete. The strain gauges were located immediately outside of the splice zone to measure the strain in the spliced bars. The deflections at the midspan, at load points, and at the supports were measured by displacement transducers. Crack comparators were used to manually measure the width of the cracks at different load levels.

\section{Test results}

General-The test results are summarized in this paper, while detailed results can be found elsewhere. ${ }^{5-9}$ The stressstrain relationships measured at UT produced the following exponential equations for modeling ASTM A1035 ${ }^{3}$ steel bars. These equations were used in all subsequent computations

$$
\begin{gathered}
f_{s}=156\left(1-e^{-220 \varepsilon_{s}}\right) \text { for No. } 5 \text { and } 8 \text { (No. } 16 \text { and 25) bars, } \\
\text { in ksi }
\end{gathered}
$$

$$
f_{s}=162\left(1-e^{-235 \varepsilon_{s}}\right) \text { for No. } 11 \text { (No. 36) bars in ksi }
$$

where $f_{s}$ is steel stress and $\varepsilon_{s}$ is steel strain.

Mode of failure-Splitting of the concrete cover was the prevailing mode of failure for all test specimens. However, five specimens tested by NCSU (refer to Tables 3 and 4), containing spliced bars confined by transverse reinforcement, failed in flexure due to crushing of the concrete in the compression zone. The high level of confinement provided by the transverse reinforcement in these five specimens resulted in a significant increase of the bond strength and enabled the specimens to achieve their flexural capacities.

Specimens with spliced bars not confined by transverse reinforcement failed suddenly in an explosive manner, with very little warning soon after the initiation of the splitting cracks, as shown in Fig. 4(a). Failure was associated with spalling and scattering of the concrete cover over the entire

\begin{tabular}{|c|c|c|c|c|c|c|c|c|c|}
\hline \multirow[b]{2}{*}{ Specimen ID } & \multirow{2}{*}{$\begin{array}{l}\text { Beam } \\
\text { length, } \mathrm{ft}\end{array}$} & \multirow{2}{*}{$\begin{array}{c}\text { Cross } \\
\text { section, in. }\end{array}$} & \multirow{2}{*}{$\begin{array}{l}\text { Splice length, } \\
\text { in. }\end{array}$} & \multirow{2}{*}{$\begin{array}{l}\text { Stirrup } \\
\text { spacing, in. }\end{array}$} & \multicolumn{3}{|c|}{ Measured cover } & \multirow{2}{*}{$\underset{\text { psi }}{\text { Measured } f_{c}^{\prime}}$} & \multirow{2}{*}{$\begin{array}{l}\text { Developed } \\
\text { stress, ksi }\end{array}$} \\
\hline & & & & & $c_{b, \text { in. }}$ & $c_{s o, \text { in. }}$ & $c_{s i, \text { in. }}$ & & \\
\hline \multicolumn{10}{|c|}{ University of Texas at Austin } \\
\hline $5-5-\mathrm{O}-\mathrm{C} 0-3 / 4$ & \multirow{6}{*}{14} & \multirow{2}{*}{$13 \times 12$} & 33 & \multirow{6}{*}{ NA } & 0.75 & 1.00 & 1.00 & 5200 & 80 \\
\hline $5-5-\mathrm{X}-\mathrm{C} 0-3 / 4$ & & & 44 & & 0.75 & 1.00 & 1.00 & 5200 & 91 \\
\hline $5-5-\mathrm{O}-\mathrm{C} 0-11 / 4$ & & \multirow{2}{*}{$35 \times 12$} & 18 & & 1.25 & 3.50 & 3.75 & 5200 & 88 \\
\hline $5-5-\mathrm{X}-\mathrm{C} 0-11 / 4$ & & & 25 & & 1.25 & 3.50 & 3.75 & 5200 & 110 \\
\hline $5-5-\mathrm{O}-\mathrm{C} 0-2.0$ & & \multirow{2}{*}{$35 \times 12$} & 15 & & 2.00 & 3.50 & 3.75 & 5700 & 97 \\
\hline $5-5-\mathrm{X}-\mathrm{C} 0-2.0$ & & & 20 & & 2.00 & 3.50 & 3.75 & 5700 & 120 \\
\hline \multicolumn{10}{|c|}{ University of Kansas } \\
\hline $5-5-\mathrm{O}-\mathrm{C} 0-3 / 4$ & \multirow{4}{*}{15} & \multirow{2}{*}{$14 \times 20$} & 32 & \multirow{4}{*}{ NA } & 0.80 & 1.11 & 1.15 & 5490 & 77 \\
\hline $5-5-\mathrm{X}-\mathrm{C} 0-3 / 4$ & & & 43 & & 0.70 & 0.96 & 1.21 & 4670 & 82 \\
\hline $5-5-\mathrm{O}-\mathrm{C} 0-1-1 / 4$ & & \multirow{2}{*}{$35 \times 10$} & 18 & & 1.09 & 3.72 & 3.76 & 5490 & 87 \\
\hline $5-5-\mathrm{X}-\mathrm{C} 0-1-1 / 4$ & & & 25 & & 0.98 & 3.80 & 3.73 & 4670 & 91 \\
\hline
\end{tabular}
length of the splice. In the slab specimens containing four

Table 2-Details of specimens with No. 5 (No. 16) spliced bars

Note: 1 in. $=25.4 \mathrm{~mm} ; 1000 \mathrm{psi}=6.895 \mathrm{MPa} ; \mathrm{NA}=$ not applicable. 


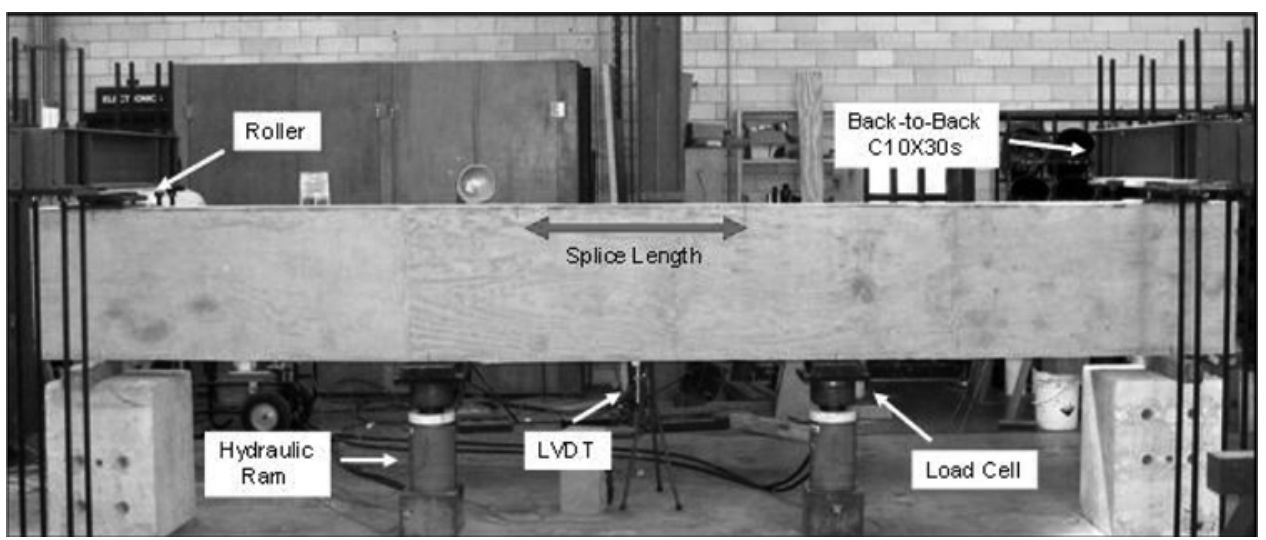

Fig. 3-Typical test setup.

No. 5 (No. 16) bar splices, the exterior splices failed before the interior splices.

The use of transverse reinforcement to confine the spliced bars resulted in a more gradual failure. The extension of splitting cracks along the spliced bars gave an indication of impending failure. Confining stirrups inhibited the progress of splitting cracks and enabled the beams to reach higher loads before failure occurred due to splitting of the concrete cover. The transverse reinforcement prevented spalling of the concrete cover over the entire splice length, as shown in Fig. 4(b), in contrast with the explosive failure shown in Fig. 4(a).

Stresses developed in spliced bars - The stresses developed in the spliced bars were determined using a cracked-section (moment-curvature) analysis of the specimens based on the measured load and Eq. (1) and (2) for the stress-strain relationships of the ASTM A $1035^{3}$ steel. Although strain gauges were attached to the spliced bars, they did not give consistent results, so the measured strains were used only as a check against the stresses developed using measure loads. The stresses developed at ultimate load, the measured concrete compressive strength on the day of testing, and the concrete covers (measured after beam failure) are given in Tables 2 to 4 .

In general, increasing the splice length, cover, confinement, or concrete strength (with other variables constant) increased the stresses developed in the spliced bars. Without transverse reinforcement, the maximum bar stresses shown in Tables 2, 3 , and 4 are 120, 110, and $96 \mathrm{ksi}(830,760$, and $665 \mathrm{MPa})$ for No. 5, No. 8, and No. 11 (No. 16, No. 25, and No. 36) bars, respectively.

Analysis of test results indicate that using long splice lengths without confinement is an inefficient way to achieve high stress levels. This is demonstrated by comparing the results of two NCSU test series, 11-5-O and 11-5-X, in which the splice lengths were 69 and 91 in (1752 and $2311 \mathrm{~mm})$. Although the splice lengths differ by $30 \%$, the developed stresses are nearly the same. Similar behavior was observed by El-Hacha et al., ${ }^{10}$ who also studied bond of high-strength bars. With long splice lengths, the bond stresses at the lead end of a splice begin to drop before the bond along the rest of the splice can be fully developed. As a result, it is not possible to mobilize high bond stresses along the entire length of a long splice. Instead, transverse reinforcement should be provided to confine the splice.

By confining the splices with sufficient cover and transverse reinforcement, the stresses developed in No. 8 and No. 11

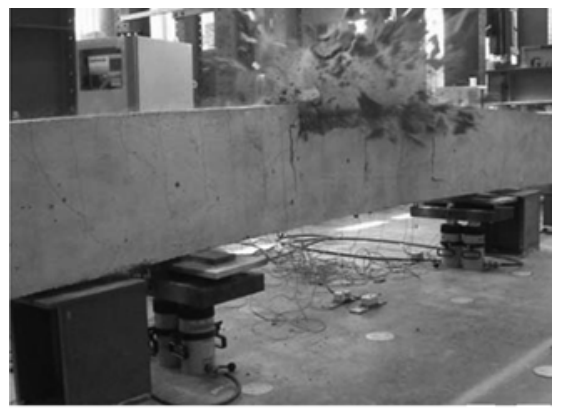

(a) Specimens with unconfined spliced bars

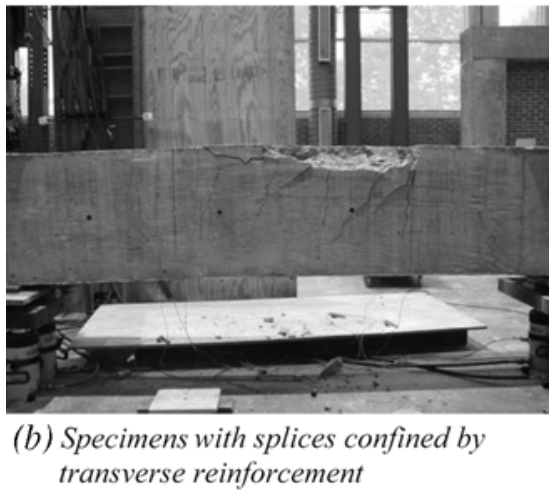

Fig. 4-Typical failure of specimens with: (a) unconfined spliced bars; and (b) splices confined by transverse reinforcement.

(No. 25 and No. 36) bars reached stresses approximately $150 \mathrm{ksi}$ (1034 MPa).

Load-deflection behavior-The load-deflection behavior of the test specimens reflects the effect of splice strength on ultimate load and deformation capacity. Load-deflection curves for specimens with different levels of transverse reinforcement containing No. 8 and No. 11 (No. 25 and No. 36) spliced bars are shown in Fig. 5 and 6, respectively.

The behavior clearly demonstrates that confining the spliced bars with transverse reinforcement increases ultimate load and deformation capacity. The increases in the ultimate load and corresponding deflection are functions of the amount of transverse reinforcement used to confine the spliced bars, and clearly show the benefits of using transverse reinforcement to improve the performance of concrete members containing spliced high-strength steel bars. 
Crack patterns-For all test specimens, the first flexural cracks formed outside the splice zone near the ends of the constant moment region; the cracks increased in number and width with increasing load. Further increases in load led to the formation of splitting cracks parallel to the reinforcing bars. The splitting cracks formed initially on the top surface of the specimen followed by splitting cracks on the side of the specimen at the level of the spliced bars, terminating at the ends of the splice. Formation of the splitting cracks had no influence on the formation and extension of flexural cracks toward the compression zone. Crack widths were measured by using crack comparators.

In Fig. 7, the stress developed in the spliced bars is plotted against measured splitting crack width for two specimens, one with unconfined splice and the other with confinement.
Splitting cracks were observed in both specimens at approximately $75 \mathrm{ksi}(520 \mathrm{MPa})$ and the crack widths were approximately $0.006 \mathrm{in} .(0.15 \mathrm{~mm})$. As the stresses increased, the splitting crack widths also increased. For a crack width of 0.02 in. $(0.51 \mathrm{~mm})$, however, the developed stress in the unconfined splice was approximately $90 \mathrm{ksi}$ (620 MPa), while the developed stress in the confined splice was approximately $120 \mathrm{ksi}(830 \mathrm{MPa})$.

Bar stresses are plotted versus flexural crack width in Fig. 8 for Specimens 8-5-O-C3-2.5 and 11-8-X-C3-3.0. The cracks reached widths of approximately 0.07 in. $(1.8 \mathrm{~mm})$ near failure of the splice at a stress level of approximately $120 \mathrm{ksi}$ (830 MPa). The stresses were approximately $50 \mathrm{ksi}(345 \mathrm{MPa})$ when crack widths of 0.016 in. $(0.41 \mathrm{~mm})$ were observedwidths considered acceptable for conventional Grade 60

Table 3-Details of specimens with No. 8 (No. 25) spliced bars

\begin{tabular}{|c|c|c|c|c|c|c|c|c|c|}
\hline \multirow[b]{2}{*}{ Specimen ID } & \multirow{2}{*}{$\begin{array}{c}\text { Beam length, } \\
\mathrm{ft}\end{array}$} & \multirow{2}{*}{$\begin{array}{c}\text { Cross section, } \\
\text { in. }\end{array}$} & \multirow{2}{*}{$\begin{array}{l}\text { Splice length, } \\
\text { in. }\end{array}$} & \multirow{2}{*}{$\begin{array}{l}\text { Stirrup } \\
\text { spacing, in. }\end{array}$} & \multicolumn{3}{|c|}{ Measured cover } & \multirow[b]{2}{*}{ Measured $f_{c}^{\prime}$, psi } & \multirow{2}{*}{$\begin{array}{l}\text { Developed } \\
\text { stress, ksi }\end{array}$} \\
\hline & & & & & $c_{b}$, in. & $c_{s o}$, in. & $c_{s i}$, in. & & \\
\hline \multicolumn{10}{|c|}{ University of Texas at Austin } \\
\hline $8-5-\mathrm{O}-\mathrm{C} 0-1.5$ & \multirow{13}{*}{18} & \multirow{7}{*}{$10 \times 27$} & \multirow{2}{*}{47} & NA & 1.50 & 1.55 & 1.45 & 5000 & 74 \\
\hline $8-5-\mathrm{O}-\mathrm{C} 2-1.5$ & & & & 5.22 & 1.50 & 1.65 & 1.38 & 5000 & 141 \\
\hline $8-5-\mathrm{X}-\mathrm{C} 0-1.5$ & & & \multirow{2}{*}{62} & NA & 1.50 & 1.50 & 1.50 & 4700 & 82 \\
\hline 8-5-X-C2-1.5 & & & & 6.89 & 1.50 & 1.60 & 1.38 & 4700 & 148 \\
\hline $8-5-\mathrm{O}-\mathrm{C} 0-1.5^{*}$ & & & \multirow{3}{*}{40} & NA & 1.50 & 1.55 & 1.45 & 5200 & 72 \\
\hline $8-5-\mathrm{O}-\mathrm{C} 1-1.5^{*}$ & & & & 13.33 & 1.50 & 1.65 & 1.38 & 5200 & 99 \\
\hline $8-5-\mathrm{O}-\mathrm{C} 2-1.5^{*}$ & & & & 6.67 & 1.50 & 1.65 & 1.38 & 5200 & 129 \\
\hline 8-8-O-C0-1.5 & & \multirow{3}{*}{$10 \times 23$} & \multirow{3}{*}{40} & NA & 1.50 & 1.60 & 1.40 & 8300 & 80 \\
\hline 8-8-O-C1-1.5 & & & & 13.5 & 1.50 & 1.65 & 1.38 & 8300 & 123 \\
\hline $8-8-\mathrm{O}-\mathrm{C} 2-1.5$ & & & & 7.0 & 1.50 & 1.65 & 1.38 & 8300 & 147 \\
\hline 8-8-X-C0-1.5 & & \multirow{3}{*}{$10 \times 27$} & \multirow{3}{*}{54} & NA & 1.50 & 1.50 & 1.50 & 7800 & 86 \\
\hline $8-8-\mathrm{X}-\mathrm{C} 1-1.5$ & & & & 18.0 & 1.50 & 1.50 & 1.50 & 7800 & 122 \\
\hline 8-8-X-C2-1.5 & & & & 9.0 & 1.50 & 1.50 & 1.50 & 7800 & 144 \\
\hline & & & & University o & nsas & & & & \\
\hline 8-5-O-C0-1.5 & \multirow{12}{*}{21} & \multirow{6}{*}{$14 \times 30$} & \multirow{3}{*}{47} & NA & 1.40 & 1.48 & 3.60 & 5260 & 78 \\
\hline $8-5-\mathrm{O}-\mathrm{C} 1-1.5$ & & & & 11.75 & 1.60 & 1.57 & 3.47 & 4720 & 124 \\
\hline $8-5-\mathrm{O}-\mathrm{C} 2-1.5$ & & & & 5.88 & 1.40 & 1.50 & 3.58 & 6050 & 127 \\
\hline 8-5-X-C0-1.5 & & & \multirow{3}{*}{63} & NA & 1.41 & 1.41 & 3.69 & 5940 & 90 \\
\hline 8-5-X-C1-1.5 & & & & 15.75 & 1.50 & 1.58 & 3.42 & 4720 & 129 \\
\hline $8-5-\mathrm{X}-\mathrm{C} 2-1.5$ & & & & 7.88 & 1.50 & 1.55 & 3.45 & 5010 & 143 \\
\hline 8-8-O-C0-2.5 & & \multirow{6}{*}{$14 \times 21$} & \multirow{3}{*}{27} & $\mathrm{NA}$ & 2.30 & 2.31 & 2.79 & 8660 & 80 \\
\hline $8-8-\mathrm{O}-\mathrm{C} 1-2.5$ & & & & 13.50 & 2.44 & 2.26 & 2.97 & 7790 & 89 \\
\hline 8-8-O-C2-2.5 & & & & 5.38 & 2.17 & 2.31 & 2.77 & 7990 & 115 \\
\hline 8-8-X-C0-2.5 & & & & NA & 2.38 & 2.44 & 2.67 & 7990 & 91 \\
\hline 8-8-X-C1-2.5 & & & 36 & 18.00 & 2.56 & 2.39 & 2.71 & 7790 & 111 \\
\hline 8-8-X-C2-2.5 & & & & 7.25 & 2.31 & 2.48 & 2.57 & 8660 & 117 \\
\hline & & & & th Carolina St & Jniversit & & & & \\
\hline $8-5-\mathrm{O}-\mathrm{C} 0-2.5$ & & & & NA & 2.50 & 2.50 & 2.50 & 6020 & 96 \\
\hline $8-5-\mathrm{O}-\mathrm{C} 2-2.5$ & & & 31 & 4.00 & 2.50 & 2.50 & 2.50 & 6020 & 140 \\
\hline $8-5-\mathrm{O}-\mathrm{C} 3-2.5^{\dagger}$ & & 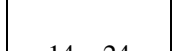 & & 2.00 & 2.50 & 2.50 & 2.50 & 6020 & 152 \\
\hline 8-5-X-C0-2.5 & & $14 \times 24$ & & NA & 2.50 & 2.50 & 2.50 & 5820 & 110 \\
\hline $8-5-\mathrm{X}-\mathrm{C} 2-2.5^{\dagger}$ & 23 & & 41 & 5.00 & 2.50 & 2.50 & 2.50 & 5820 & 152 \\
\hline $8-5-\mathrm{X}-\mathrm{C} 3-2.5^{\dagger}$ & & & & 2.50 & 2.50 & 2.50 & 2.50 & 5820 & 152 \\
\hline 8-8-O-C0-1.5 & & & (1) & NA & 1.50 & 1.50 & 1.50 & 8400 & 91 \\
\hline 8-8-O-C2-1.5 & & $10 \times 24$ & 40 & 7.50 & 1.50 & 1.50 & 1.50 & 8400 & 151 \\
\hline 8-8-X-C0-1.5 & & $10 \times 24$ & 54 & $\mathrm{NA}$ & 1.50 & 1.50 & 1.50 & 10,200 & 109 \\
\hline $8-8-\mathrm{X}-\mathrm{C} 2-1.5$ & & & 54 & 10.50 & 1.50 & 1.50 & 1.50 & 10,200 & 152 \\
\hline
\end{tabular}


(Grade 420) steel. Also shown in Fig. 8 is the stress level at $60 \%$ of the failure stress $(90 \mathrm{ksi}$ [620 MPa]) and its corresponding crack width, as well as the stress level of $60 \mathrm{ksi}(415 \mathrm{MPa}$ ) with its corresponding crack width. The $60 \mathrm{ksi}$ (415 MPa) stress level is most likely close to the actual service load stress level with $100 \mathrm{ksi}(690 \mathrm{MPa})$ as design yield strength. Because of the greater flexural crack width at stresses above $50 \mathrm{ksi}$ (345 MPa), designers will have to weigh the acceptability of larger crack widths than are now considered acceptable if higher-strength steels are used for flexural design.

\section{Calculated stresses}

The design equations in ACI $318-05^{1}$ (Eq. (3) and (4)) and those recommended by ACI Committee $408^{2}$ (Eq. (5) and (6)) are used to calculate the maximum stresses developed in the spliced bars. In Eq. (3) and (5), the bar stress $f_{s}$ has been

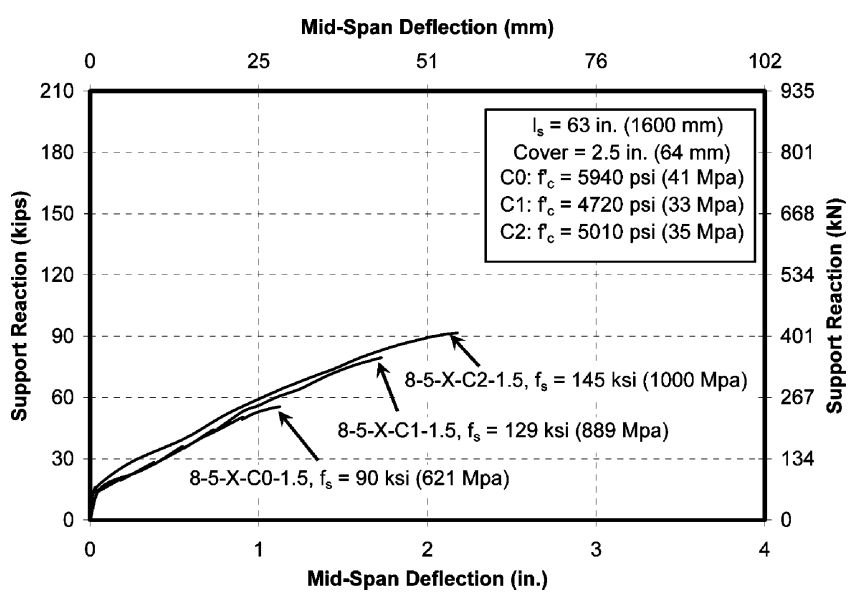

Fig. 5-Load-deflection behavior of beams with No. 8 (No. 25) bars (8-5-X-CO,C1,C2-1.5).

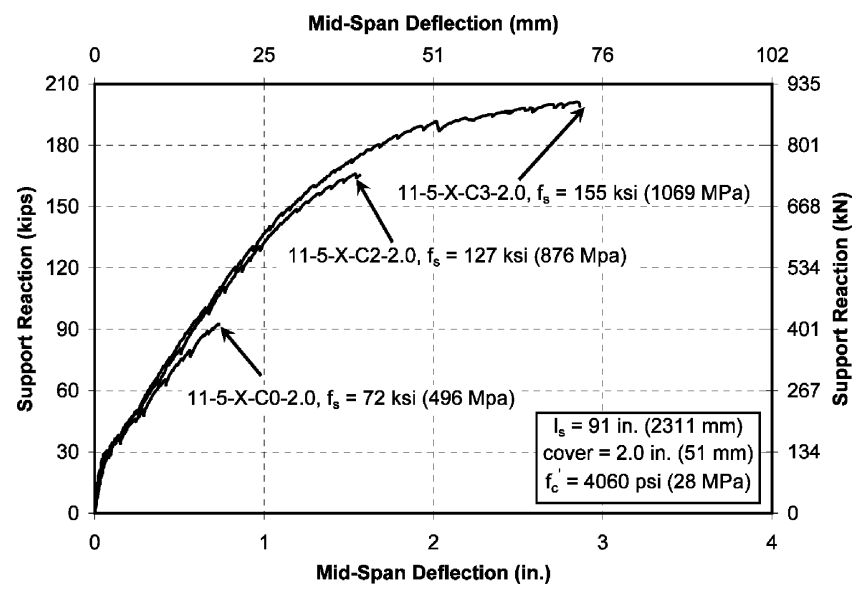

Fig. 6-Load-deflection behavior of beams with No. 11 (No. 36) bars (11-5-X-CO,C1,C3-2.0).

Table 4-Details of specimens with No. 11 (No. 36) spliced bars

\begin{tabular}{|c|c|c|c|c|c|c|c|c|c|}
\hline \multirow[b]{2}{*}{ Specimen ID } & \multirow{2}{*}{$\begin{array}{c}\text { Beam length, } \\
\mathrm{ft}\end{array}$} & \multirow{2}{*}{$\begin{array}{c}\text { Cross section, } \\
\text { in. }\end{array}$} & \multirow{2}{*}{$\begin{array}{c}\text { Splice length, } \\
\text { in. }\end{array}$} & \multirow{2}{*}{$\begin{array}{l}\text { Stirrup } \\
\text { spacing, in. }\end{array}$} & \multicolumn{3}{|c|}{ Measured cover } & \multirow[b]{2}{*}{ Measured $f_{c}^{\prime}$, psi } & \multirow{2}{*}{$\begin{array}{l}\text { Developed } \\
\text { stress, ksi }\end{array}$} \\
\hline & & & & & $c_{b}$, in. & $c_{s o}$, in. & $c_{s i}$, in. & & \\
\hline \multicolumn{10}{|c|}{ University of Texas at Austin } \\
\hline $11-5-\mathrm{O}-\mathrm{C} 0-3.0$ & \multirow{6}{*}{22} & \multirow{6}{*}{$18 \times 31$} & \multirow{3}{*}{50} & $\mathrm{NA}$ & 2.75 & 3.25 & 2.88 & 5000 & 75 \\
\hline $11-5-\mathrm{O}-\mathrm{C} 1-3.0$ & & & & 8.33 & 2.75 & 3.25 & 3.00 & 5000 & 104 \\
\hline $11-5-\mathrm{O}-\mathrm{C} 2-3.0$ & & & & 4.17 & 2.75 & 3.25 & 3.00 & 5000 & 128 \\
\hline $11-5-\mathrm{X}-\mathrm{C} 0-3.0$ & & & \multirow{3}{*}{67} & NA & 2.75 & 3.13 & 3.00 & 5400 & 84 \\
\hline $11-5-\mathrm{X}-\mathrm{C} 1-3.0$ & & & & 11.17 & 2.75 & 3.13 & 2.94 & 5400 & 117 \\
\hline $11-5-\mathrm{X}-\mathrm{C} 2-3.0$ & & & & 5.58 & 2.75 & 3.13 & 2.94 & 5400 & 141 \\
\hline \multicolumn{10}{|c|}{ University of Kansas } \\
\hline $11-8-\mathrm{O}-\mathrm{C} 0-2.0$ & \multirow{6}{*}{24} & \multirow{6}{*}{$24 \times 26$} & \multirow{3}{*}{58} & NA & 1.89 & 1.89 & 7.41 & 9370 & 68 \\
\hline 11-8-O-C1-2.0 & & & & 14.50 & 1.63 & 1.76 & 7.52 & 9370 & 96 \\
\hline $11-8-\mathrm{O}-\mathrm{C} 2-2.0$ & & & & 6.50 & 2.00 & 2.00 & 7.18 & 8680 & 124 \\
\hline 11-8-X-C0-2.0 & & & \multirow{3}{*}{79} & NA & 1.85 & 1.95 & 7.32 & 9910 & 79 \\
\hline $11-8-\mathrm{X}-\mathrm{C} 1-2.0$ & & & & 19.75 & 2.01 & 2.11 & 7.18 & 9910 & 107 \\
\hline $11-8-\mathrm{X}-\mathrm{C} 2-2.0$ & & & & 8.75 & 2.00 & 2.00 & 7.18 & 8680 & 137 \\
\hline \multicolumn{10}{|c|}{ North Carolina State University } \\
\hline $11-5-\mathrm{O}-\mathrm{C} 0-2.0$ & \multirow{12}{*}{23} & \multirow{6}{*}{$14 \times 36$} & \multirow{3}{*}{69} & NA & 2.00 & 2.00 & 2.00 & 5340 & 74 \\
\hline $11-5-\mathrm{O}-\mathrm{C} 2-2.0$ & & & & 6.50 & 2.00 & 2.00 & 2.00 & 5340 & 132 \\
\hline $11-5-\mathrm{O}-\mathrm{C} 3-2.0$ & & & & 3.00 & 2.00 & 2.00 & 2.00 & 5340 & 151 \\
\hline $11-5-\mathrm{X}-\mathrm{C} 0-2.0$ & & & \multirow{3}{*}{91} & NA & 2.00 & 2.00 & 2.00 & 4060 & 72 \\
\hline $11-5-\mathrm{X}-\mathrm{C} 2-2.0$ & & & & 8.00 & 2.00 & 2.00 & 2.00 & 4060 & 127 \\
\hline $11-5-\mathrm{X}-\mathrm{C} 3-2.0$ & & & & 4.00 & 2.00 & 2.00 & 2.00 & 4060 & 155 \\
\hline $11-8-\mathrm{O}-\mathrm{C} 0-3.0$ & & \multirow{6}{*}{$18 \times 24$} & \multirow{3}{*}{43} & NA & 3.00 & 3.00 & 3.00 & 6070 & 78 \\
\hline $11-8-\mathrm{O}-\mathrm{C} 2-3.0$ & & & & 5.50 & 3.00 & 3.00 & 3.00 & 6070 & 116 \\
\hline 11-8-O-C3-3.0* & & & & 2.50 & 3.00 & 3.00 & 3.00 & 6070 & 152 \\
\hline $11-8-\mathrm{X}-\mathrm{C} 0-3.0$ & & & \multirow{3}{*}{57} & NA & 3.00 & 3.00 & 3.00 & 8380 & 96 \\
\hline $11-8-\mathrm{X}-\mathrm{C} 2-3.0$ & & & & 7.00 & 3.00 & 3.00 & 3.00 & 8380 & 128 \\
\hline $11-8-\mathrm{X}-\mathrm{C} 3-3.0^{*}$ & & & & 3.50 & 3.00 & 3.00 & 3.00 & 8380 & 157 \\
\hline
\end{tabular}

*Specimens failed in flexure by crushing of concrete.

Note: 1 in. $=25.4 \mathrm{~mm} ; 1000 \mathrm{psi}=6.895 \mathrm{MPa}$; NA = not applicable. 
substituted for $f_{y}$ in the design equations, and the terms for reinforcement location, epoxy-coated bars, and lightweight concrete have been removed because they do not apply for the specimens tested in this study.

$$
\begin{gathered}
\ell_{d}=\frac{3}{40} \frac{f_{s}}{\sqrt{f_{c}}} \frac{\Psi_{s}}{\left(\frac{c_{b}+K_{t r}}{d_{b}}\right)} d_{b} \\
K_{t r}=\frac{A_{t r} f_{y t}}{1500 s n}
\end{gathered}
$$

where $A_{t r}$ is the total cross-sectional area of all transverse reinforcement that is within the spacing $s$ and crosses the potential plane of splitting through the reinforcement being developed or lap spliced, in. ${ }^{2} ; c_{b}$ is the smaller of: (a) the distance from center of a bar to nearest concrete surface, and (b) one-half the center-to-center spacing of bars being developed, in.; $d_{b}$ is nominal bar diameter of developed or lap spliced bar, in.; $\sqrt{f_{c}^{\prime}}$ is the square root of concrete compressive strength, expressed in psi units; $f_{y t}$ is the yield strength of transverse reinforcement, psi, taken as 60,000 psi (414 MPa) for this study; $\ell_{d}$ is the development length (also splice length in this study), in.; $n$ is the number of bars being

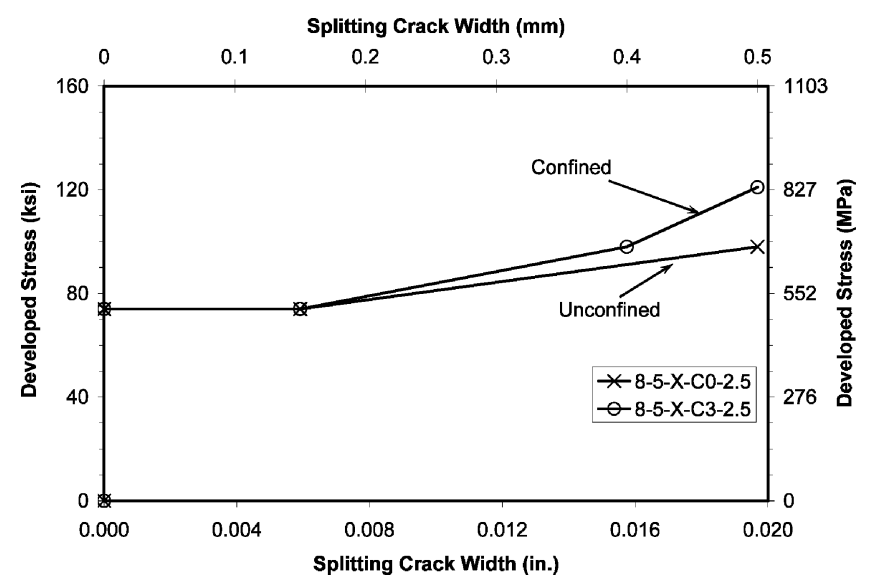

Fig. 7-Splitting crack width of beams of second group (8-5-X-CO-2.5 and 8-5-X-C3-2.5).

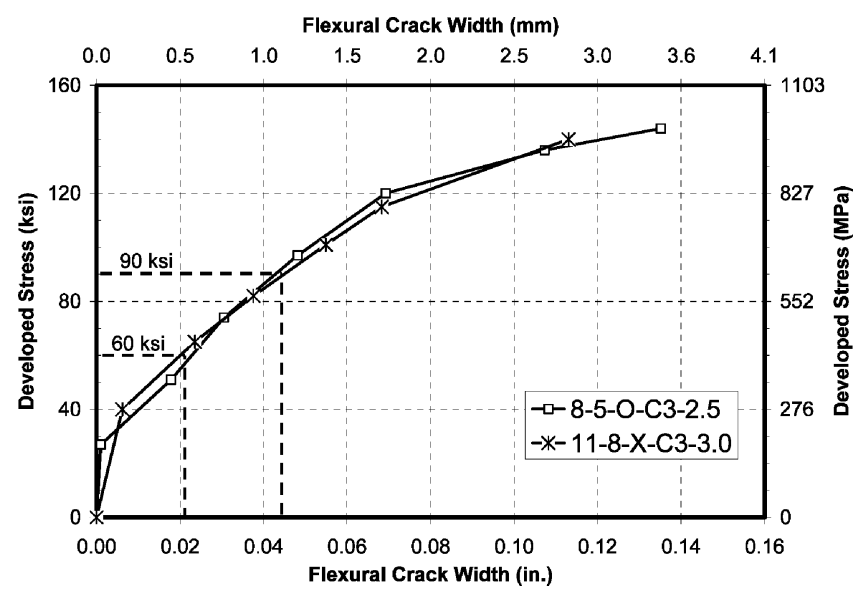

Fig. 8-Flexural crack width of beams 8-5-O-C3-2.5 and $11-8-X-C 3-3.0)$. developed or lap spliced along plane of splitting; $s$ is the maximum center-to-center spacing of transverse reinforcement within $\ell_{d}$, in.; and $\psi_{s}$ is the reinforcement size factor. For No. 6 (No. 19) and smaller bars and deformed wires, $\psi_{s}=0.8$. For No. 7 (No. 22) and larger bars, $\psi_{s}=1.0$.

$$
\begin{gathered}
\ell_{d}=\frac{\left(\frac{f_{s}}{f_{c}^{, 1 / 4}}-\phi 2400 \omega\right)}{\phi 76.3\left(\frac{c_{b} \omega+K_{t r}}{d_{b}}\right)} \\
K_{t r}=\left(0.5 t_{d} A_{t r} / s n\right) \sqrt{f_{c}^{\prime}}
\end{gathered}
$$

where $c_{b}=c_{\text {min }}+0.5 d_{b}$, in.; $c_{b b}$ is clear cover of reinforcement being developed or lap spliced, measured to tension face of member, in.; $c_{\text {max }}$ is the maximum value of $c_{s}$ or $c_{b b}$, in.; $c_{\text {min }}$ is the minimum value of $c_{s}$ or $c_{b b}$, in.; $c_{s}$ is the minimum value of $c_{s i}+0.25$ in. or $c_{s o}$, in.; $c_{s i}$ may be used instead of $c_{s i}+0.25$ in.; $c_{s i}$ is one-half of average clear spacing between bars or lap splices in a single layer, in.; $c_{s o}$ is clear cover of reinforcement being developed or lap spliced, measured to side face of member, in.; $f_{c}{ }^{1 / 4}$ is the fourth root of, expressed in psi units; $t_{d}$ is the bar diameter factor $=0.78 d_{b}+0.22$; and $\omega$ is the factor reflecting benefit of large cover/spacing perpendicular to controlling cover/spacing $=0.1\left(c_{\text {max }} / c_{\text {min }}\right)$ $+0.9 \leq 1.25$.

Both developed stresses and calculated stresses, obtained by solving Eq. (3) and (5) for $f_{s}$, are given in Table A.1 for unconfined splices. The same results for confined splices are given in Table A.2. The five specimens that failed in flexure are excluded from Table A.2. A strength reduction factor ( $\phi$-factor) does not appear in Eq. (3) because it is already included in the expression; while $\phi=0.82$ is used in Eq. (5).

Table A.1 shows that the average developed/calculated strength ratio for splices without confining transverse reinforcement for ACI 318-05 is 0.87 (coefficient of variation $[\mathrm{COV}]=0.20)$, while the average developed/calculated strength ratio for ACI 408R-03 is $1.19(\mathrm{COV}=0.11)$, with 25 and 2 out of 31 tests with ratios less than 1.0 for ACI 318-05 and ACI 408R, respectively.

For confined splices, the averages of developed/calculated splice strength ratios are $1.10(\mathrm{COV}=0.21)$ for ACI 318-05 and 1.29 $(\mathrm{COV}=0.10)$ for ACI 408R-03 (ACI 408R-03, Table 6), with 10 and zero out of 33 tests with ratios less than 1.0 for ACI 318-05 and ACI 408R, respectively. The scatter of developed/calculated strength ratios is shown in Fig. 9.

Overall, Eq. (5) and (6) (ACI 408R) provide a reasonable estimate of strength for both unconfined and confined splices using a strength reduction factor ( $\phi$-factor) of 0.82 and design parameters (cover, spacing, and concrete strengths) comparable to those used in this test program. Equations (3) and (4) (ACI 318) are less conservative, with a large percentage of the developed/calculated strength ratios below 1.0, and should not be used for development and splice design with high-strength reinforcing steel.

\section{CONCLUSIONS}

The following conclusions are based on the test results and analyses presented in this paper:

1. The failure of beams with spliced bars not confined by transverse reinforcement was sudden and produced explosive 

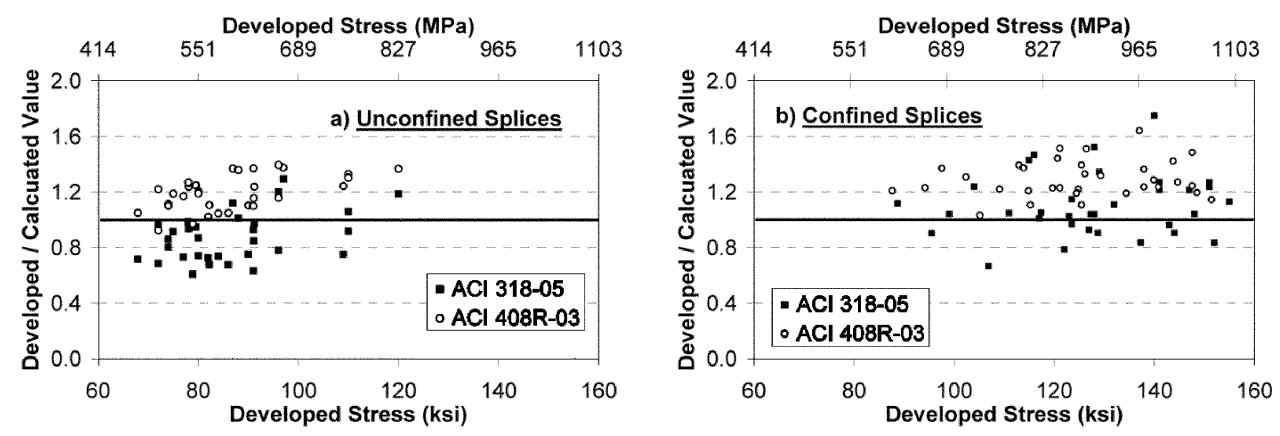

Fig. 9-Distribution of developed/calculated values of spliced bars: (a) unconfined splices; and (b) confined splices.

spalling of the concrete cover over the entire splice length. Observation of first splitting cracks was an indication of imminent failure;

2. The use of transverse reinforcement to confine the spliced bars allowed splitting cracks to develop along the spliced bars and spalling of the cover was more gradual;

3. Without transverse reinforcement, the maximum bar stresses developed were 120,110, and $96 \mathrm{ksi}(830,760$, and $665 \mathrm{MPa}$ ) for No. 5, No. 8, and No. 11 (No. 16, No. 25, and No. 36) bars, respectively;

4. By confining the ASTM A1035 spliced bars with transverse reinforcement, bar stresses at bond failure of up to $150 \mathrm{ksi}$ (1035 MPa) were reached for No. 8 and No. 11 (No. 25 and No. 36) bars;

5. The presence of stirrups to confine the spliced bars limited the progress of the splitting cracks and led to both higher strength and greater beam deformation before failure. However, the transverse reinforcement had no effect on the initiation of the splitting cracks;

6. The average developed/calculated splice strength ratio for unconfined splices using the ACI 318-05 equations is 0.87 , with a COV of 0.20 . Using the equation recommended by ACI Committee 408, the average is 1.19 , with a COV of 0.11 ;

7. For confined splices, the ACI 318-05 and the ACI Committee 408 equations led to developed/calculated splice strength ratios of 1.10 and 1.29 , respectively. The COVs are 0.21 and 0.10 , respectively;

8. Increasing splice lengths to satisfy splice strength requirements may not be sufficient if high stress levels are to be developed without the use of transverse reinforcement; and

9. The ACI Committee 408 equation provides a reasonable estimate of the strength for both unconfined and confined splices using a strength reduction factor ( $\phi$-factor) of 0.82 and design parameters (cover, spacing, and concrete strengths) comparable to those used in this test program. The design equations in ACI 318 are less conservative, with a large percentage of the developed/calculated strength ratios below 1.0 , and should not be used for development and splice design with high-strength reinforcing steel in their present form.

\section{ACKNOWLEDGMENTS}

The authors gratefully acknowledge the support of MMFX Technologies Corporation for sponsoring this study and supplying the steel materials. The authors would also like to thank the technical staff and graduate students who helped with the laboratory work at each institution.

\section{REFERENCES}

1. ACI Committee 318, "Building Code Requirements for Structural Concrete (ACI 318-05) and Commentary (318R-05)," American Concrete Institute, Farmington Hills, MI, 2005, 430 pp.

2. ACI Committee 408, "Bond and Development of Straight Reinforcing in Tension ACI 408R-03)," American Concrete Institute, Farmington Hills, MI, 2003, 49 pp.

3. ASTM A1035/A1035M-07, "Standard Specification for Deformed and Plain, Low-Carbon, Chromium, Steel Bars for Concrete Reinforcement," ASTM International, West Conshohocken, PA, 2007, 5 pp.

4. ASTM A370-07, "Standard Test Methods and Definitions for Mechanical Testing of Steel Products," ASTM International, West Conshohocken, PA, 2007, 47 pp.

5. Briggs, M.; Miller, S.; Darwin, D.; and Browning, J., "Bond Behavior of Grade 100 ASTM A1035 Reinforcing Steel in Beam-Splice Specimens," SL Report 07-01, The University of Kansas Center for Research Inc., Lawrence, KS, Aug. 2007 (revised Oct. 2007), 83 pp.

6. Glass, G. M., "Performance of Tension Lap Splices with MMFX High Strength Reinforcing Bars," MSc thesis, University of Texas at Austin, Austin, TX, 2007, 141 pp.

7. Hosny, A., "Bond Behavior of High Performance Reinforcing Bars for Concrete Structures," MSc thesis, North Carolina State University, Raleigh, NC, 2007, 150 pp.

8. Seliem, H. M., "Behavior of Concrete Bridges Reinforced with HighPerformance Steel Reinforcing Bars," PhD dissertation, North Carolina State University, Raleigh, NC, 2007, 259 pp.

9. Seliem, H. M.; Hosny, A.; and Rizkalla, S., "Evaluation of Bond Characteristics of MMFX Steel," Technical Report No. RD-07-02, Constructed Facilities Laboratory (CFL), North Carolina State University, Raleigh, NC, 2007, 71 pp.

10. El-Hacha, R.; El-Agroudy, H.; and Rizkalla, S., H., "Bond Characteristics of High-Strength Steel Reinforcement," ACI Structural Journal, V. 103, No. 6, Nov.-Dec. 2006, pp. 771-782. 


\section{APPENDIX}

Table A.1-Calculated stresses in unconfined splices (31 specimens)

\begin{tabular}{|c|c|c|c|c|c|}
\hline \multirow[b]{2}{*}{ Specimen ID } & \multirow[b]{2}{*}{ Developed stress, ksi } & \multicolumn{2}{|c|}{ ACI $318-05^{2}$} & \multicolumn{2}{|c|}{ ACI $408 \mathrm{R}-03^{3}$} \\
\hline & & Calculated stress, ksi & Developed/calculated & Calculated stress, ksi & Developed/calculated \\
\hline \multicolumn{6}{|c|}{ University of Kansas } \\
\hline $5-5-\mathrm{O}-\mathrm{C} 0-3 / 4$ & 77 & 105 & 0.73 & 66 & 1.17 \\
\hline $5-5-\mathrm{X}-\mathrm{C} 0-3 / 4$ & 82 & 122 & 0.68 & 74 & 1.11 \\
\hline $5-5-\mathrm{O}-\mathrm{C} 0-11 / 4$ & 87 & 78 & 1.12 & 63 & 1.37 \\
\hline $5-5-\mathrm{X}-\mathrm{C} 0-11 / 4$ & 91 & 94 & 0.97 & 74 & 1.24 \\
\hline $8-5-\mathrm{O}-\mathrm{C} 0-1.5$ & 78 & 84 & 0.94 & 63 & 1.24 \\
\hline $8-5-\mathrm{X}-\mathrm{C} 0-1.5$ & 90 & 120 & 0.75 & 82 & 1.10 \\
\hline 8-8-O-C0-2.5 & 80 & 84 & 0.95 & 64 & 1.25 \\
\hline 8-8-X-C0-2.5 & 91 & 107 & 0.85 & 79 & 1.16 \\
\hline $11-8-\mathrm{O}-\mathrm{C} 0-2.0$ & 68 & 95 & 0.72 & 65 & 1.05 \\
\hline $11-8-\mathrm{X}-\mathrm{C} 0-2.0$ & 79 & 130 & 0.61 & 81 & 0.97 \\
\hline \multicolumn{6}{|c|}{ University of Texas at Austin } \\
\hline $5-5-\mathrm{O}-\mathrm{C} 0-3 / 4$ & 80 & 108 & 0.74 & 66 & 1.20 \\
\hline $5-5-\mathrm{X}-\mathrm{C} 0-3 / 4$ & 91 & 144 & 0.63 & 83 & 1.10 \\
\hline $5-5-\mathrm{O}-\mathrm{C} 0-11 / 4$ & 88 & 87 & 1.01 & 65 & 1.36 \\
\hline $5-5-\mathrm{X}-\mathrm{C} 0-11 / 4$ & 110 & 120 & 0.92 & 83 & 1.33 \\
\hline $5-5-\mathrm{O}-\mathrm{C} 0-2.0$ & 97 & 75 & 1.29 & 71 & 1.38 \\
\hline $5-5-\mathrm{X}-\mathrm{C} 0-2.0$ & 120 & 101 & 1.19 & 88 & 1.37 \\
\hline 8-5-O-C0-1.5 & 74 & 86 & 0.86 & 66 & 1.11 \\
\hline 8-5-X-C0-1.5 & 82 & 113 & 0.73 & 80 & 1.02 \\
\hline 8-5-O-C0-1.5* & 72 & 75 & 0.96 & 59 & 1.22 \\
\hline 8-8-O-C0-1.5 & 80 & 92 & 0.87 & 67 & 1.19 \\
\hline 8-8-X-C0-1.5 & 86 & 127 & 0.68 & 82 & 1.05 \\
\hline $11-5-\mathrm{O}-\mathrm{C} 0-3.0$ & 75 & 82 & 0.91 & 63 & 1.19 \\
\hline $11-5-\mathrm{X}-\mathrm{C} 0-3.0$ & 84 & 114 & 0.74 & 80 & 1.05 \\
\hline \multicolumn{6}{|c|}{ North Carolina State University } \\
\hline 8-5-O-C0-2.5 & 96 & 80 & 1.20 & 69 & 1.39 \\
\hline 8-5-X-C0-2.5 & 110 & 104 & 1.06 & 84 & 1.30 \\
\hline 8-8-O-C0-1.5 & 91 & 98 & 0.93 & 66 & 1.37 \\
\hline 8-8-X-C0-1.5 & 109 & 145 & 0.75 & 88 & 1.24 \\
\hline $11-5-\mathrm{O}-\mathrm{C} 0-2.0$ & 74 & 92 & 0.80 & 67 & 1.10 \\
\hline $11-5-\mathrm{X}-\mathrm{C} 0-2.0$ & 72 & 105 & 0.69 & 78 & 0.92 \\
\hline $11-8-\mathrm{O}-\mathrm{C} 0-3.0$ & 78 & 79 & 0.99 & 62 & 1.27 \\
\hline $11-8-\mathrm{X}-\mathrm{C} 0-3.0$ & 96 & 123 & 0.78 & 83 & 1.16 \\
\hline & & & 0.87 & Average & 1.19 \\
\hline & & & 0.18 & Standard deviation & 0.13 \\
\hline & & & 0.20 & $\mathrm{COV}$ & 0.11 \\
\hline & & & 1.29 & Maximum & 1.39 \\
\hline & & & 0.61 & Minimum & 0.92 \\
\hline
\end{tabular}


Table A.2-Calculated stresses in confined splices (33 specimens)

\begin{tabular}{|c|c|c|c|c|c|}
\hline \multirow[b]{2}{*}{ Specimen ID } & \multirow[b]{2}{*}{ Developed stress, ksi } & \multicolumn{2}{|c|}{ ACI $318-05^{2}$} & \multicolumn{2}{|c|}{ ACI 408R-03 ${ }^{3}$} \\
\hline & & Calculated stress, ksi & Developed/calculated & Calculated stress, ksi & Developed/calculated \\
\hline \multicolumn{6}{|c|}{ University of Kansas } \\
\hline $8-5-\mathrm{O}-\mathrm{C} 1-1.5$ & 124 & 108 & 1.15 & 82 & 1.51 \\
\hline $8-5-\mathrm{O}-\mathrm{C} 2-1.5$ & 127 & 122 & 1.04 & 104 & 1.22 \\
\hline $8-5-X-C 1-1.5$ & 129 & 142 & 0.91 & 97 & 1.33 \\
\hline $8-5-\mathrm{X}-\mathrm{C} 2-1.5$ & 143 & 149 & 0.96 & 111 & 1.29 \\
\hline $8-8-\mathrm{O}-\mathrm{C} 1-2.5$ & 89 & 79 & 1.12 & 73 & 1.21 \\
\hline $8-8-\mathrm{O}-\mathrm{C} 2-2.5$ & 115 & 80 & 1.43 & 83 & 1.39 \\
\hline 8-8-X-C1-2.5 & 111 & 106 & 1.05 & 91 & 1.22 \\
\hline $8-8-\mathrm{X}-\mathrm{C} 2-2.5$ & 117 & 112 & 1.05 & 106 & 1.11 \\
\hline $11-8-\mathrm{O}-\mathrm{C} 1-2.0$ & 96 & 106 & 0.90 & 78 & 1.23 \\
\hline $11-8-\mathrm{O}-\mathrm{C} 2-2.0$ & 124 & 128 & 0.97 & 100 & 1.23 \\
\hline 11-8-X-C1-2.0 & 107 & 161 & 0.66 & 103 & 1.03 \\
\hline $11-8-\mathrm{X}-\mathrm{C} 2-2.0$ & 137 & 164 & 0.84 & 115 & 1.19 \\
\hline \multicolumn{6}{|c|}{ University of Texas at Austin } \\
\hline $8-5-\mathrm{O}-\mathrm{C} 2-1.5$ & 141 & 111 & 1.27 & 103 & 1.36 \\
\hline $8-5-\mathrm{X}-\mathrm{C} 2-1.5$ & 148 & 142 & 1.04 & 116 & 1.27 \\
\hline $8-5-\mathrm{O}-\mathrm{C} 1-1.5^{*}$ & 99 & 95 & 1.04 & 72 & 1.37 \\
\hline $8-5-\mathrm{O}-\mathrm{C} 2-1.5^{*}$ & 129 & 96 & 1.34 & 85 & 1.51 \\
\hline 8-8-O-C1-1.5 & 123 & 120 & 1.03 & 85 & 1.44 \\
\hline $8-8-\mathrm{O}-\mathrm{C} 2-1.5$ & 147 & 121 & 1.21 & 103 & 1.42 \\
\hline 8-8-X-C1-1.5 & 122 & 155 & 0.79 & 99 & 1.23 \\
\hline 8-8-X-C2-1.5 & 144 & 159 & 0.91 & 116 & 1.24 \\
\hline $11-5-\mathrm{O}-\mathrm{C} 1-3.0$ & 104 & 84 & 1.24 & 80 & 1.31 \\
\hline $11-5-\mathrm{O}-\mathrm{C} 2-3.0$ & 128 & 84 & 1.52 & 92 & 1.39 \\
\hline $11-5-\mathrm{X}-\mathrm{C} 1-3.0$ & 117 & 116 & 1.01 & 97 & 1.21 \\
\hline $11-5-\mathrm{X}-\mathrm{C} 2-3.0$ & 141 & 116 & 1.22 & 114 & 1.24 \\
\hline \multicolumn{6}{|c|}{ North Carolina State University } \\
\hline $8-5-\mathrm{O}-\mathrm{C} 2-2.5$ & 140 & 80 & 1.75 & 85 & 1.64 \\
\hline 8-8-O-C2-1.5 & 151 & 122 & 1.24 & 102 & 1.49 \\
\hline $8-8-\mathrm{X}-\mathrm{C} 2-1.5$ & 152 & 182 & 0.84 & 127 & 1.20 \\
\hline $11-5-\mathrm{O}-\mathrm{C} 2-2.0$ & 132 & 119 & 1.11 & 100 & 1.32 \\
\hline $11-5-\mathrm{O}-\mathrm{C} 3-2.0$ & 151 & 119 & 1.27 & 121 & 1.24 \\
\hline $11-5-\mathrm{X}-\mathrm{C} 2-2.0$ & 127 & 137 & 0.93 & 107 & 1.19 \\
\hline $11-5-\mathrm{X}-\mathrm{C} 3-2.0$ & 155 & 137 & 1.13 & 135 & 1.15 \\
\hline $11-8-\mathrm{O}-\mathrm{C} 2-3.0$ & 116 & 79 & 1.47 & 84 & 1.37 \\
\hline $11-8-\mathrm{X}-\mathrm{C} 2-3.0$ & 128 & 123 & 1.04 & 116 & 1.11 \\
\hline & & & 1.10 & Average & 1.29 \\
\hline & & & 0.23 & Standard deviation & 0.13 \\
\hline & & & 0.21 & $\mathrm{COV}$ & 0.10 \\
\hline & & & 1.75 & Maximum & 1.64 \\
\hline & & & 0.66 & Minimum & 1.03 \\
\hline
\end{tabular}

